\title{
Contents and Countermeasures of Cultivating Students' Cross-Cultural Communicative Awareness in English Teaching
}

\author{
Jie Chen ${ }^{\mathrm{a}}$, Chunhua Cui ${ }^{\mathrm{b}}$ \\ College of Foreign Languages, Bohai University, Jinzhou, 121013, China \\ acarnation2009@163.com, ${ }^{b} 13841603520 @ 163 . c o m$
}

Keywords: English teaching; cross-cultural communicative awareness; contents; countermeasures

\begin{abstract}
Cross-cultural communicative competence is the ultimate goal of English education, and language education is also largely cultural education. Therefore, the cultivation of students' cross-cultural communicative awareness in English teaching is the need for totally carrying out the quality education, the need to cultivate students' communicative competence, and the need to cultivate students' foreign language thinking ability. The content of cultivating students' cross-cultural communication in English teaching includes: language skills, language knowledge, emotional attitudes, learning strategies and cultural consciousness. In view of the problems of cultivating students' cross-cultural communicative awareness in English teaching, the countermeasures are as follows: the introduction of flipped class model, the guide of students' extensive contact with Western cultural materials, the use of new media resources to feel the real context, in-depth study of vocabulary and idiom culture background.
\end{abstract}

\section{Introduction}

Language is a part of culture and plays an important role in culture. Language is the cornerstone of culture, there is no language without culture; language is influenced by culture and reflect the culture. The relationship between language and culture can be roughly conclude from the following three aspects: First, language is an important part of culture. Culture includes the material wealth and spiritual wealth created by mankind, which is the spiritual wealth created in the process of human evolution and is part of the culture. The language of a society is one aspect of the social culture, and language and culture are part and the whole. Second, the language is a mirror, reflecting a nation's culture, revealing the content of the national culture. Through a national language, you can understand the national customs, lifestyles thinking characteristics and other cultural characteristics. Third, language and culture interact and mutual restraint each other. Language is the tool of thinking, and the composition of culture can not be separated from thinking, language to a certain extent, affect and control the thinking method, scope and depth. When the thinking develops to a certain extent, the language form can not meet the needs or impede its development, people will transform the thinking tools to promote language changes. In this sense, thinking affects and restricts the language. Due to language-cultural relation research, we have a great inspiration for a language, and do not isolate ourselves to learn a language, only to constantly understand the target language country or region culture, can really thoroughly learn and master a language.

Communication refers to the information of intercourse and exchange process between people, which is a multiple elements composed of the interaction between the continuous process. Communication is not carried out in a vacuum zone, but always in a certain social and cultural environment. Therefore, the communication process and the various elements will continue to be affected by environmental factors. When the various elements of cultural become different, that is, cross-cultural communication. Good interpersonal skills and good interpersonal relationships are necessary conditions for survival and development. Cross-cultural communication is a kind of communicative behavior, as for the type of communication, can be interpersonal communication, can be communication between individuals and groups of communication. With economic globalization and the continuous development of information network, the globalization has become 
an irreversible trend, people from different geographical and cultural background daily form the status of citizenship in the world, the cross-cultural communication ability will become people's basic survival skills. Because of the lack understanding of the importance of cross-cultural communication, it is usually possible to talk with foreigners by talking about the ability of listening, speaking, reading, and writing in English teaching and we always think communicative ability is equivalent to the basic skills of English. University teachers in English teaching only focus on the language form of students is correct, language use is smooth, less emphasis on the use of language specific occasions. English teaching in all aspects, the appearance that heavy form and light culture is more serious, general lack of systematic cultural knowledge education background. Cross-cultural communicative competence is the ultimate goal of English education, and language education is also a great cultural and educational education. College English teaching process needs to cultivate students 'awareness of cross-cultural communication and improve students' intuition and sensitivity to cultural differences and practical application of language.

\section{Effects of Cultivating Students' Cross-Cultural Communicative Awareness in English Teaching}

In the globalization background in order to meet the needs of communication, dissemination, application of knowledge, material creation and spiritual wealth, the higher education personnel not only need to have solid professional knowledge, but also must have a high cross-cultural communication skills, so as to meet social and national needs for development. Cultivating foreign language talents with cross-cultural communicative competence is one of the main goals for foreign language teaching. Foreign language education circle generally agreed that the purpose of foreign language teaching is to cultivate students' cross-cultural communication skills. Foreign language teaching must meet the needs of the times, the cross-cultural communication ability training as a teaching goal, to make foreign language teaching really serve the community, to cultivate students should be able to become natural, appropriate and effective exchange of ideas and information under the cross-cultural communication practice, then win in the fierce world competition. English is the most important foreign language teaching language in China, and it is important to cultivate students' awareness of cross-cultural communication in English teaching.

(1) The need for full implementation of quality education. Quality education is based on the actual needs of human development and social development, in order to comprehensively improve the basic quality of all students as the fundamental purpose, respecting the personality of students, paying attention to the development of people's physical and mental potential, and focusing on the formation of human health as the fundamental characteristics of education. The Quality education and cross-cultural education are the pursuit of integrity and rich personality, both educators and sociologists, are deeply aware of the internal relationship must be unified. Cross-cultural education is an effective way to develop educational horizons, update educational concepts and improve quality education. College English teaching emphasizes cross-cultural communication, because communication can not only participate in the quality of education practice, but also to guide the existing educational resources and educational development.

(2) The need for cultivating students' communicative competence. For a long time, English teaching pays too much attention on grammar and vocabulary, the text is divided into words and sentences, the meaning of the text become a boring article, which can not mobilize students' interest in learning, but the growth of weariness, suppress the desire of mastering language, making language knowledge scattered, which is not conducive for students to master and form a certain language skill. English teaching should do a good job in basic education to train students' language communication skills. "Listening, speaking, reading, writing" is a kind of ability, but no matter how strong this ability, is not the real ability to communicate. Communicative competence must be obtained through communicative activities. Only applied "listen, say, read, write" to the real context, we can produce real communication skills.

(3) The need for cultivating students' thinking ability in foreign languages. Thinking has an important influence on language, and cross-cultural communication is a complex process involving 
language, culture and thinking. English thinking refers to the mastery degree of English is the same as the mother tongue, can be flexible use, pure English expression thought, and the formation of instinctive, conditioned reflex way of thinking. Different learners with different cultural backgrounds has different thinking model, English learners in the learning process need to strengthen the awareness of cross-cultural communication, systematic learning of Western culture, improve the sensitivity of Chinese and Western cultural differences and perception, take initiative to understand the differences in national culture, prevent language errors, reduce the occurrence of barriers to communication. To improve the sensitivity of cultural differences, that is, through the objective non-judgment of contrast, we have an correct understanding of Chinese and English culture's different thinking with contrast and identification.

\section{Contents of Cultivating Students' Cross-Cultural Communicative Awareness in English Teaching}

RG Hanvey divides cross-cultural awareness into four levels: the first level, through the tourism, magazines and textbooks, etc., to understand the obvious and the surface cultural characteristics, at this time, the communicators feel novel and incredible; the second level, Through the cultural conflict, perceived subtle cultural characteristics contrasted with their own culture, at this time, the communicator is confused, irritable and incredible; the third level, through rational analysis, understand the culture contrasted with their own control, at this time, the communicators found that these cultural characteristics are credible and able to recognize; the fourth level, through cultural immersion, in-depth experience, real understanding, and even agree with each others actions. The first level and the second level is relatively easy to achieve, teachers can through the film, magazines, QQ and WeChat for students to provide a large number of cultural knowledge input, improve cultural knowledge learning interest; and then highlight the contradictory problems, so students use Cross-cultural communication theory to guide and analyze the rational discussion and analysis, guide them to understand the confusion of cross-cultural communicators, from the psychological and behavioral understanding to the existence of cultural differences, explore the root causes of conflict and coping strategies. Through this discussion, students can transform abstract theory into concrete events, improve cross-cultural awareness and sensitivity to cross-cultural events, and then naturally transition to the third level, frankly accept and rational analysis cultural conflict. The fourth level is difficult to achieve, but good cross-cultural communicators should be committed to achieving this level. In order to achieve this goal, students can experience the real cross-cultural communication, encourage students to use a wide range of resources and developed information technology, improve cross-cultural awareness and sensitivity. In the actual English teaching, according to this level of division gradually realized, need to cultivate students' cross-cultural sense of communication as shown in Fig.1.

Fig. 1 shows that in English teaching, cultivate students cross-cultural communication awareness of the content, including language skills, language knowledge, emotional attitudes, learning strategies and cultural awareness about five areas. Among them, language skill, "listening, speaking, reading, writing" is the basic comprehensive use of the ability in the content of training and form as close as possible to the actual life to students, close to the real communicative behavior, close to the purpose of the comprehensive use of English activities; Language knowledge, language knowledge learning must be consolidation in the process of language learning skill activities. "Listening, speaking, reading, writing" is to improve the "voice, vocabulary, grammar, topic" and other basic knowledge of the quality of teaching which is a reliable guarantee; learning strategies, teachers change the teaching concept, strengthen the awareness of learning strategies, raise understanding and reduce the negative impact on student learning strategies. Combined with language learning, and gradually develop learning strategies; emotional attitudes, requires communicators with cross-cultural communication awareness, respect for other cultures, overcome ethnocentrism, racism and other communication barriers. Cultural awareness, cultural awareness is a kind of cultural group members' behavior habits, ideas, views and values, but also means the understanding 
of the behaviors and the cause of faith in group of members. Cultural teaching is the main means to improve cultural awareness.

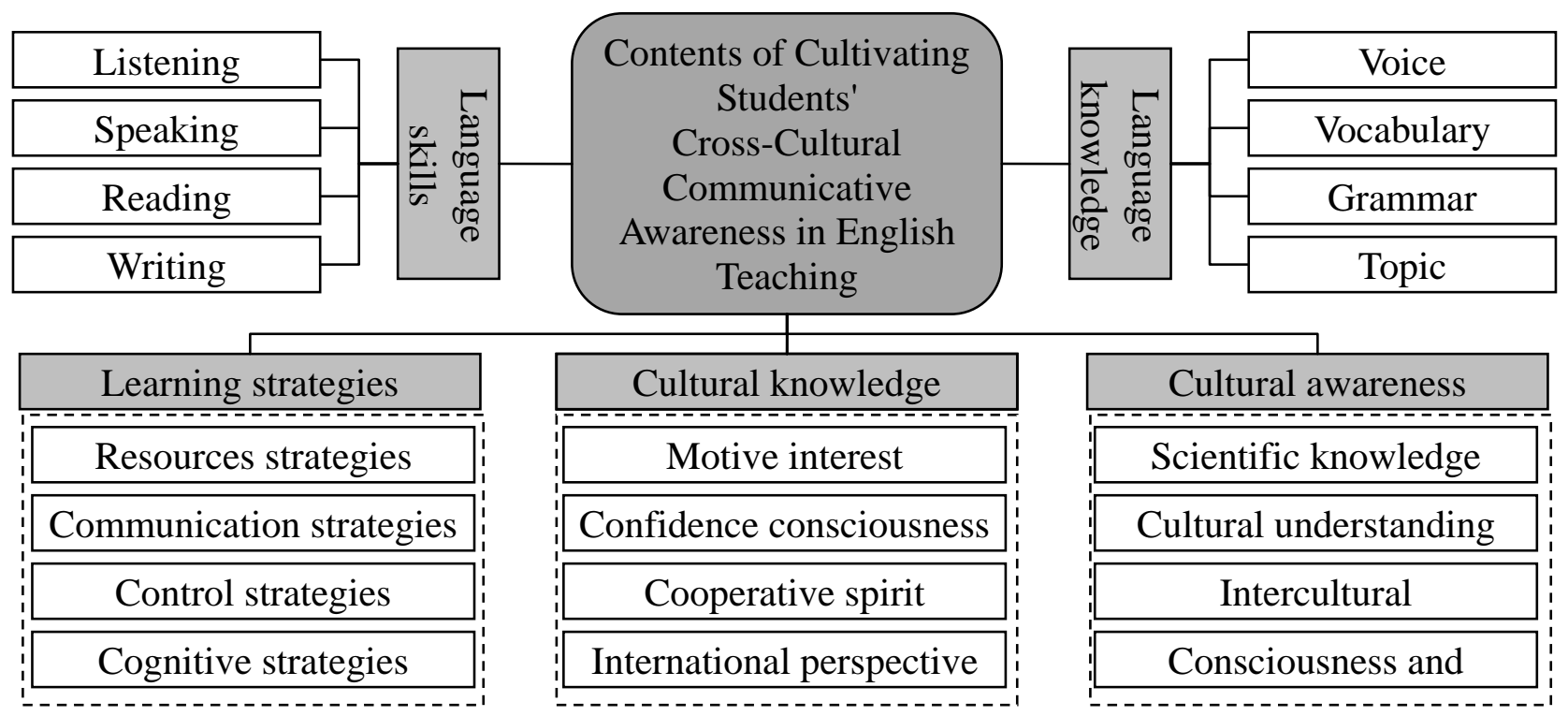

Fig. 1. Contents of cultivating students' cross-cultural communicative awareness in English teaching

\section{Countermeasures of Cultivating Students' Cross-Cultural Communicative Awareness in English Teaching}

English teaching should adopt flexible approach to improve students' sensitivity to culture, cultivate cross-cultural awareness and improve their communicative competence. So students can take the initiative to consciously absorb and integrate into the new cultural environment, better grasp the use of this language. Achieve the students' ability to cross-cultural communication, students need to help learn a lot of cultural content, in addition to learning English language knowledge, but also must contact the rich cultural connotation of English. Teachers should use effective teaching methods to penetrate the cultural elements in the teaching process, and students should also take effective learning methods to actively absorb the English cultural connotation, and ultimately achieve the purpose of cross-cultural communication. The specific strategies of cultivating students' awareness of cross-cultural communication in English teaching are as follows:

(1) Introduce flipped teaching model. The rotation of the classroom is based on the theory of autonomous learning, constructivism and mixed learning theory, re-adjust the time inside and outside the classroom, teachers no longer occupy the classroom time to teach information, the transfer of decision to learn from teachers to students. Students use their own teaching methods and to meet the needs of students and promote personalized learning, the goal is to enable students to practice through more real learning. Rotate the classroom to make the two processes reverse, in the absorption of internalization in this link, which can be transferred from the students outside the classroom, in the learning effect and knowledge construction, based on their actual ability and foundation, in line with the principle of individualized; The focus of the rotated classroom is to give the classroom autonomy to the students, and teachers only through assistance and communication to assist students to learn, students according to their own needs, free to establish knowledge system.

(2) Guide students to widely contact Western cultural materials. Use a variety of channels and a variety of means to understand, absorb and experience Western culture. Teachers collect articles and pictures in English-speaking countries, and students understand the foreign art, history and customs; the use of English movies, television, slides and video and other information, to let the students have intuitive feelings, really master the actual use of English. Introduce students simple reading of foreign culture, increase understanding of English culture; invite Chinese and foreign education experts according to the cultural differences to do between China and foreign special 
report; organize the English Corner, English party and other language practice activities, create a variety of language environment, and strengthen the practical application of cultural knowledge.

(3) Use new media resources to feel real context. The new media era create favorable conditions for college students to cultivate cross - cultural communication consciousness. New media not only has a lot of language and cultural learning resources, but also has a large platform for cross-cultural communication. Radio and television broadcast, European and American film, television programs, electronic newspapers, foreign websites, tourism, dining, cartoon and other resources, a true reflection of all aspects from social materials, so that students can explore to relatively real cultural environment, to maximize the true foreign cultural context, foreigners real daily life, the accumulation of exotic cultural background, customs, lifestyle and social relations and other aspects of knowledge, and improve cultural understanding. Teachers should take advantage of students' initiative, enthusiasm and creativity, make full use of new media technologies and resources, construct meaningful learning environments, promote and support students' learning activities.

(4) Depth study of cultural background in vocabulary and idioms. In English learning, students need to learn a lot of vocabulary and idioms, vocabulary and idioms is the most to reflect the characteristics of national culture with broad connotation and extension. Both English and Chinese have a lot of vocabulary and idioms, but they root in two distinct cultural environments, with very different national image and cultural color. Many vocabulary and idioms clearly reflect the differences between Chinese and Western cultures, and the study of vocabulary and idioms can profoundly understand the differences between Chinese and Western cultures. Therefore, from the beginning of vocabulary and idiom teaching, we must consciously pay attention to compare the two cultural differences, so that students can better understand vocabulary, and improve the cross-cultural communication skills.

\section{Acknowledgement}

This work is supported by social science fund project of Liaoning province: Research on English Spread Problems in Modern Chinese and Western Communication (L16BYY007).

\section{References}

[1] Y. J. Wang, Y. L. Zhang, "Cross cultural communication and English teaching," Education Teaching Forum, vol. 9, no. 5, pp. 85-86, 2017.

[2] Y. Y. Zhang, "Cultivation of Students' Cross-cultural Communicative Competence in College English Teaching," Learning Weekly, vol. 10, no. 10, pp. 5-7, 2016.

[3] Baidu Knows, "The relationship between language and culture," https://zhidao.baidu.com/question/580939285.html, 2017-3-5.

[4] H. Y. Sun, "'One Belt And One Road' under the perspective of intercultural communication curriculum content," Journal of Shandong University of Technology (social sciences), vol. 33, no. 1, pp. 83-87, 2013

[5] M. M. Xu, "On the cultivation of students' intercultural communicative competence in Business English Teaching," Journal of Hubei University of Science and Technology, vol. 36, no. 2, pp. 134-136, 2016.

[6] N. Ma, "Train Culture Awareness Improve Cross - Cultural Communication Function," The Border Economy and Culture, vol. 12, no. 5, pp. 115-116, 2015.

[7] H. Jin, "How to develop intercultural communicative competence in English Teaching," Curriculum, Teaching Material and Method, vol. 35, no. 11, pp. 80-85, 2015.

[8] X. R. Hu, "On the cultivation of students' intercultural communicative competence in College English teaching," Neijiang Technology, vol. 18, no. 1, pp. 70-71, 2017.

[9] C. P. Ge, S. R. Wang, "On Cultivation of Intercultural Communicative Competence in College English Teaching," Foreign Languages and Their Teaching, vol. 9, no. 2, pp. 79-86, 2016. 